\title{
The Essentials of Conservation Agriculture for Soil Quality, Crop and Water Productivity in Ethiopian Agriculture: A Review
}

\author{
Temesgen Fentahun Adamtie \\ Ethiopian Institute of Agricultural Research, Pawe Agricultural Research Centre P. O. Box 25, Pawe Ethiopia
}

\begin{abstract}
In fact food security can be increased through improved land use and land management practices. In Ethiopia much of the increase in crop production in the past decade has been due to increases in area of cultivated. To what extent expansion can continue remains a question, therefore obtaining higher yield rates is the challenge of Ethiopia's agricultural system. Conservation agriculture (mulching); which here refers to minimizing soil disturbance through no-till practice, application of organic mulch cover, and cropping in time; has the potential to improve soil quality, water, and crop productivity. The objectives of this critical review is to collect available information in similar production environments, indicators on the essential of CA contributions to soil quality, crop and water productivity both in dry and rainfall seasons of Ethiopian agriculture. Recently a study on the role of conservation agriculture indicates improve soil quality, crop yield and water productivity. In addition to this CA can be protect soil layer for erosions either wind or runoff, to optimize infiltration rate minimize runoff, to crate the path of soil it contributes micro nutrients move easily. So, reviewer concluded that conservation agriculture is potentially important to improve sustainable Ethiopian agricultural production and productivity. This agricultural practice (CA) should be able to adopt for irrigated and rain fed farms of Ethiopia.
\end{abstract}

Keywords: Conservation Agriculture, soil quality, crop productivity, water productivity and Ethiopia

DOI: $10.7176 / \mathrm{JNSR} / 12-16-03$

Publication date:August $31^{\text {st }} 2021$

\section{Introduction}

Food security can be increased through improved land use and land management practices (Branca et al., 2013; van der Molen, 2017; Ramankutty et al., 2018), Agriculture in the next decade will have to produce more food on less land (Hobbs, 2007; Hobbs et al., 2008; Govers et al., 2017) and purchased production inputs by making more efficient use of natural and applied resources but with a minimal negative impact on the environment (Stagnari et al., 2009; Meemken and Qaim, 2018; Baylis et al., 2021). In Ethiopia much of the increase in crop production in the past decade has been due to increases in area cultivated. To what extent expansion can continue remains a question, therefore obtaining higher yield rates is the challenge of Ethiopia's agricultural system.

Conservation agriculture is the integration of ecological management with modern, scientific, agricultural production (Assefa et al., 2020; Abebe et al.). According to Derpsch et al. (2010) Conservation Agriculture was started with concept of reduced tillage or no tillage practices in 1970s in USA. Conservation agriculture (CA), defined as minimal soil disturbance (no-till, NT) and permanent soil cover (mulch) combined with rotations, as a more sustainable cultivation system for the future (Hobbs, 2007). Conservation agriculture (CA) aims to conserve, improve, and make more efficient use of natural resources through integrated management of (Abebe et al.)soil, water, and biological resources combined with external inputs(Hobbs, 2007; Hobbs et al., 2008; Leye, 2007; Stagnari et al., 2009). It contributes to environmental conservation as well as to enhanced and sustained agricultural production. It can also be referred to as resource-efficient or resource effective agriculture (Govers et al., 2017).

In recent times researchers are sound to deliver positive impacts of CA adoption on soil quality and crop yield improvement (Das et al., 2014; Jat et al., 2018; Nangia et al., 2010; Assefa, 2018; Assefa et al., 2020; Yimam et al., 2020; Assefa et al., 2021). The soil quality improvements are around enhancement of soil organic carbon (SOC) content (Yimam et al., 2020), water infiltration capacity (Abera et al., 2020), water holding capacity and microbial activities (Abera et al., 2020), and thereby arresting decline in total factor productivity of applied inputs. Moreover, it was reported to have contributed to protection of the top fertile soil from wind and water erosion (Nangia et al., 2010; Descheemaeker et al., 2013; Fentahun Adametie, 2020).

In Ethiopia, land degradation in the form of soil erosion, nutrient depletion, soil compaction, and increased salinization and acidity pose a serious threat to sustainable intensification and diversification of agricultural production systems. Ethiopian farmers have been practicing excessive soil tillage using animal traction for thousands of years (Goe, 1987) as cited by (Getnet et al., 2015). Tillage is physical, chemical, or biological soil manipulation to optimize conditions for seed germination, emergence, and seedling establishment (Getnet et al., 2015; Lal, 1976). Smallholder farmers in Ethiopia practice traditional tillage systems using an ard plow called Maresha (Nyssen et al., 2011) . Traditional tillage systems that involve repeated cultivations with the Maresha 
plow have caused land degradation) and poor utilization of rain water that led to low crop productivity (Leye, 2007). Reports showed that Ethiopia loss $40-130 \mathrm{t} \mathrm{ha}^{-1}$ year ${ }^{-1}$ of soil from croplands that costs the country about 1.0-1.5 million tons loss of grain production per year (Abera et al., 2020). Reduction in soil fertility and soil quality are among major factors contributing to low adaptability of agriculture to insufficient and erratic rainfall in many parts of the country (Alemu and Mengistu, 2019; Ariti et al., 2015). Research on conservation agriculture in Ethiopia started early in 1980s (Georgis and Sinebo, 1993) with the focus of reducing heavy disturbance from frequent tillage operations by the traditional tillage implement, Maresha plow (Melesse et al., 2007). Reports on crop performance and soil productivity improvements in most trials of zero and minimum tillage showed varying results in different soils and rainfall conditions (Assefa et al., 2019; Assefa et al., 2021; Belay et al., 2020). In addition to this for irrigation seasons studies have examined drip irrigation in combination with $\mathrm{CA}$ is one of the best strategies for soil and water management that improves the cycles of vegetable production through increased water productivity (Yimam et al., 2020; Assefa, 2018). Application of surface organic mulch cover has been used to improve soil water retention, reduce soil temperature and reduce wind velocity at the soil surface and arid lands (Yimam et al., 2020; Bainbridge et al., 2001). Surface organic mulch can also improve water penetration by impeding runoff and protecting the soil from raindrop splash and reducing soil crusting (Munshower, 1994). In recent studies, the effects of conservation agriculture with irrigation improves crop yield and also soil carbon and nitrogen were increased (Assefa et al., 2019; Assefa et al., 2020; Yimam et al., 2020; Belay et al., 2020). So, this review pepper was troubled to conservation agriculture (CA); which here refers to minimizing soil disturbance through no-till practice, application of organic mulch cover, and cropping in time; has the potential to improve soil quality, water, and crop productivity. Therefore the objectives of this review work is to collect available information in similar production environments, indicators on the essential of CA contributions to soil quality, crop and water productivity both in dry and rainfall seasons of Ethiopian agriculture.

\section{History of Agricultural practice in Ethiopia}

The history of tillage dates back many millennia when humans changed from hunting and gathering to more sedentary and settled agriculture mostly in the Tigris, Euphrates, Nile, Yangste and Indus river valleys (Hillel, 1991) as cited by (Hobbs et al., 2008). From those Ethiopia is the source of Blue Nile the agriculture is generally dominated by smallholder, rain-fed, low-input-low-output mode of production (Agerie, 2013) Since, Ethiopian farmers have been practicing excessive soil tillage using animal traction for thousands of years (Goe, 1987) as cited by (Getnet et al., 2015). Tillage is physical, chemical, or biological soil manipulation to optimize conditions for seed germination, emergence, and seedling establishment (Getnet et al., 2015; Lal, 1976). Smallholder farmers in Ethiopia practice traditional tillage systems using an ard plow called Maresha (Nyssen et al., 2011; Leye, 2007). Traditional tillage systems that involve repeated cultivations with the Maresha plow have caused land degradation) and poor utilization of rainwater that led to low crop productivity (Leye, 2007). Much of the increase in crop production in the past decade has been due to increases in area cultivated. To what extent expansion can continue remains a question, therefore obtaining higher yield rates is the challenge of Ethiopia's agricultural system.

\section{Conservational Agricultural practice in Ethiopia}

Soil and Water Conservation in Ethiopia has a long history. According to Beshah (2003) the traditional terraces in Konso constitute a spectacular example of a living cultural tradition stretching back to more than 400 years. The soil conservation practices, including minimum or no tillage have long been practiced by farmers with different approaches or systems in Ethiopia (Rockström et al., 2009). From the observation indigenously Ethiopian farmers were applied plant residue (mulching) for nursery and perennial crops like hop and coffee. This applied residue (CA) is used to protect sun light and conserve soil moisture for long time. Conservation agriculture and its associated package of best practices were introduced in 1980 (Abera et al., 2020). with the focus of reducing heavy disturbance from frequent tillage operations by the traditional tillage implement, Maresha plow (Leye, 2007). Whereas the adoption and expansion of conservation agriculture for Ethiopian farmers is still under expected. Agricultural policies input subsidy policies, investments in agricultural extension and access to markets in predicting are challenges for CA adoption (Marenya et al., 2015).

\section{Crop production and productivity in Ethiopia}

Both irrigated and rain-fed agriculture is important in the Ethiopian economy. Nevertheless, virtually all food crops $(97 \%)$ in Ethiopia come from rain fed agriculture, with the irrigation subsector accounting for only about (3\%) of the food crops (Awulachew and Merrey, 2007; Mendes and Paglietti, 2015). Cereals dominate Ethiopian crop production were grown on $73.4 \%$ of the total area cultivated, by a total of 11.2 million farmers and obtained 12 million tons per year of cereals, which is $68 \%$ of total agricultural production (Mebratu et al., 2015). Irrigated crops in medium and large-scale commercial farms are mostly cash crops, in particular cotton and sugar 
cane, but fruits and vegetables were also introduced (Girma and Seleshi, 2007). In small-scale irrigation schemes, irrigated crops are more diversified, but for the country as a whole, the main irrigated crops are cereals-maize, wheat, barley or teff, pulses, vegetables, root crops, fruits, and fiber crops (cotton) (Neelakantam and Naidu, 2016). Smallholder irrigators generally prefer subsistence crops rather than cash crops (Muhanji et al., 2011) and use irrigation to complement rain fed agriculture, i.e. Supplementary irrigation rain-fed, during the dry season, they use full irrigation to get additional income (IWMI, 2009).

According to Central Statistical Agency Ethiopia (2011); CSA (2019), the agricultural Sample Survey report of Ethiopia on area and production of crops as categorized grain crops, vegetables, root crops, and fruit crops. Crop production farms are classified as private smallholder rain-fed farms, Private smallholder dry season irrigation farms, and Commercial farms (Table, 1). Those farms coverage and productivity of grain crop shows a total land area of 15,270,526 hectares and 342, 17454.3 ton. Vegetables, It covers $1.96 \%$ at the national level and contributes $2.17 \%$ of the total crop production. Root crops, it covers $1.62 \%$ of the area under all crops at the national level. Fruit crops, it covers 107,890.60 hectares and obtained more than 7, 923, 66.5 ton per year.

As compared to farm type's crop productivity showed that irrigated farm is good productivity while rain fed and commercial farms are less productivity of grain, cereals, pulses and oilseeds.

Table 1: source CSA (2019); Ethiopia (2011) crop coverage area and crop production for Ethiopia under irrigated, rain fed and commercial

\begin{tabular}{llllllllll}
\hline Farm type & \multicolumn{1}{l}{ Irrigated } & \multicolumn{3}{l}{ Rain fed } & \multicolumn{3}{l}{ Commercial } \\
\hline $\begin{array}{l}\text { Crop } \\
\text { Category }\end{array}$ & $\begin{array}{l}\text { Area } \\
\text { (ha) } \\
\times 103\end{array}$ & $\begin{array}{l}\text { Production } \\
\text { ton x103 }\end{array}$ & $\begin{array}{l}\text { Productivity } \\
\text { ton ha }^{-1}\end{array}$ & $\begin{array}{l}\text { Area } \\
\text { (ha) } \\
\times 103\end{array}$ & $\begin{array}{l}\text { Production } \\
\text { ton x103 }\end{array}$ & $\begin{array}{l}\text { Productivity } \\
\text { ton ha-1 }\end{array}$ & $\begin{array}{l}\text { Area } \\
\text { (ha) } \\
\times 103\end{array}$ & $\begin{array}{l}\text { Production } \\
\text { ton x103 }\end{array}$ & $\begin{array}{l}\text { Productivity } \\
\text { ton ha-1 }\end{array}$ \\
\hline Grain Crops & 85.3 & 287.52 & 3.4 & 14543 & 32605.5 & 2.2 & 641. & 1324.34 & 2.1 \\
Cereals & 70.4 & 262.01 & 3.7 & 11610 & 28392.2 & 2.4 & 296. & 970.23 & 3.3 \\
Pulses & 14.8 & 25.4 & 1.7 & 2053. & 3353.48 & 1.6 & 58.8 & 111.17 & 1.9 \\
Oilseeds & 0.1 & 0.12 & 1.2 & 879.6 & 0.86 & 0.0 & 286. & 242.95 & 0.8 \\
Total & 170. & 575.05 & 3.4 & 29086 & 64352.1 & 2.2 & 1283 & 2648.69 & 2.1 \\
\hline
\end{tabular}

N.B: Area of cultivated and productions of yield data taken from CSA for irrigated, rain fed and commercial while productivity of each was changed by researcher

\section{Role of Conservation Agriculture for soil, crop and water productivity}

There are numbers of soil and crop management practices that can increase the crop yields and water productivity (Yi et al., 2010). CA (Mulching) is a cropping practice that entails placing organic or inorganic or synthetic materials on soil close to plants to provide a more favorable environment for the growth and development of crops (Ranjan et al., 2017; Kumar and Lal, 2012). The application of mulching practices reduces soil evaporation, conserve soil moisture, suppresses weed growth, control soil structure and temperature, influences soil micro-organisms and increase crop productivity(Kader et al., 2017) and reduction of runoff and erosion (Ranjan et al., 2017). It dampens the influence of the environmental factor on the soil by controlling seasonal fluctuations in soil temperature (Ghosh et al., 2006). Especially, using a sufficient mulching layer could control both weed growth and soil temperature fluctuations (Ji and Unger, 2001). Moreover, the water holding capacity of soil is improved through mulch decomposition and humus formation (Liu et al., 2013).

Agricultural production increase under CA by improving soil physical properties and fertility (Bandyopadhyay et al., 2009). Mulching is very useful in protecting the roots of the plants from heat, cold, or drought or to keep fruit clean (Kumar and Lal, 2012). Mulching have also effective change in increasing horticultural crop production in water scarcity regions (Lal Bhardwaj, 2013). Additionally, organic mulch protect the crop from soil born disease and provided plant nutrition (Stirling and Eden, 2008) and nutrients leaching loses can also be minimized (Zibilske and Makus, 2009) and improve crop production through increasing soil quality by conserving soil moisture (Ranjan et al., 2017), enhancing soil biological activities, and improving the chemical and physical properties of soil (Bandyopadhyay et al., 2009).

Conservation Agriculture with Drip Irrigation for Water Productivity in Sub-Saharan Africa including Ethiopia studied by Assefa et al. (2019) suggested that irrigation water use was substantially lower under CA, $18 \%$ to $45.6 \%$, with a substantial increase in crop yields, $9 \%$ to about two-fold, when compared with CT practice for the various vegetables.

\subsection{Essentials of CA for Soil quality}

Mulching with agricultural waste such as straw, compost, grass clippings, and leaves, and others had increased water retention and prevented the soil evaporation (Kar and Singh, 2004). Straw is the most commonly used material for ground covering in the crop and vegetable production because of its good thermal insulation properties. The temperature of the soil under the straw can be 5-80C lower than the temperature of bare soil which is especially important in the summer (OLJAČA et al., 2018). Straw mulching increase WUE, crop 
growth, and grain yield over none mulch (Kar and Singh, 2004). Straw mulching has the ability to improving the soil structure, water-holding capacity, and increase the soil moisture content of the soil, and the amount of water stored in soil increased as the application of mulching rate increases (Liu et al., 2013).

Organic mulches preserve more soil moisture (Ghosh et al., 2006) and (Teame et al., 2017). Mulch played a dominant role in the conservation of soil water even if in the condition of moderate stress (Mukherjee et al., 2012). Organic mulch consistently helped in retaining higher soil water than without mulch and reduced soil temperature by 2-3oc (Ghosh et al., 2006).

Moisture contents of soils of irrigated tomato under grass straw, rice straw, rice husk and sawdust mulches were higher than those in the non-mulching (Nkansah et al., 2003). Liu et al. (2010) studied soil water dynamics and water use efficiency in spring maize field under different water management practices on the loess plateau and the result indicates that soil water storage increased in the straw mulch compared to film mulch. Dissimilarly, (Shirgure et al., 2003) study reported that black polyethylene mulching conservation higher soil moisture than soybean straw and grass mulching. Straw mulching increases the soil moisture content of apple orchard (Liu et al., 2013) and maize crop (Tao et al., 2015). Straw mulch conserves soil water by reducing the incoming solar energy, less water was evaporated and mulch reduced the soil moisture depletion in irrigated potato plant (Kar and Kumar, 2007).

In most cases, water stored in the soil increases with increasing mulching rate. Ji and Unger (2001) reported that straw mulching rate increases form $2.0 \mathrm{Mg} \mathrm{ha}^{-1}$ to $4.0 \mathrm{Mg} \mathrm{ha}^{-1}$ soil water storage efficiency increase by 60 to $100 \%$, respectively compared with bare soil. Harmoniously, Ahmed et al. (2007) suggested that soil moisture content increase from 2 to $24 \%$ as the mulching rate increase from 1 to 4 tons per hectare. The effectiveness of increasing mulching rate on soil moisture reserve was studied by Uwah and Iwo (2011), the result indicated that soil moisture reserves were highest at mulching rate increases compared with non-mulch.

In Ethiopian case Liben et al. (2018) experimental report showed that CA increases by the rate of water infiltration $15 \%$, time-to-pond doubled and soil organic carbon $4 \mathrm{~g} \mathrm{~kg}-1$ as compared with conventional practice.

\subsection{Essential of CA for plant growth and yield}

Application of organic mulch more over straw mulching is superior to that of inorganic mulch to provide the highest yield of crops (Ghosh et al., 2006) and facilitate better crop growth and development (Teame et al., 2017). Organic mulching is one of the suitable methods for the production of horticultural and vegetable crops with quality products (Ranjan et al., 2017). Organic mulch increase yield to the extent of more than $50 \%$ if the soil moisture is conserved (Ranjan et al., 2017). Saeed and Ahmad (2009) stated that organic mulches with or without gypsum to the soil being irrigated with saline water increases the yield of tomato by reducing salinity. Seifu et al. (2017) suggested that organic mulching has a significant effect on plant height and earliness maturity of garlic crops than bare soil. Identically, Teame et al. (2017) reported that straw mulch increases number of seed per capsule, seed weight, and grain yield of sesame. In contrast ${ }^{7148}$ (Malik et al., 2017) reported that Black Film Mulch significantly increased the yield of sugar beet by $4 \%$ over straw mulch.

Ghosh et al. (2006) suggested that wheat straw mulch increase yield of ground nut by $30-40 \%$ over without mulch and wheat or paddy straw produced $17-24 \%$ of higher yield of ground nut over polythene mulch. In contrast Liu et al. (2010), suggested that maize grain yield was increased in film mulch rather than straw mulch. Mukherjee et al. (2012) reported that mulching increases tomato yield by $23-57 \%$ over non mulching condition. Maize yield was increased by $233.9 \mathrm{~kg} / \mathrm{ha}-381.8 \mathrm{~kg} / \mathrm{ha}$ in chopped straw mulching over prostrate whole straw mulching (Tao et al., 2015). In Ethiopia reported by (Liben et al., 2018) studied at Melkassa and Bako agricultural research center who obtained maize grain yield was $10.14 \mathrm{Mg}$ ha-1 for conventional practice compared with $9.01 \mathrm{Mg}$ ha-1 for CA in 2015 at Bako, but maize yields were greater with CA at Melkassa in 2016. Monoculture and intercrop dry bean, respectively, had 40 and 32\% more grain yield with CA compared to CP in 2016 at Melkassa. It was concluded that medium-term beneficial effects of CA on soil properties and crop productivity can be expected at Melkassa, but any short-term benefits of CA at Bako were uncertain.

Mubarak and Hamdan (2018) suggested that mulching increase onion bulb yield by 53.4\% compared to none mulching. According to Inusah et al. (2013) onion bulb yield was improved under straw mulching rather than non-mulching. Onion yield in both grass and rice straw mulches were significantly different from one another; onion yield under grass mulching was increased by $60 \%$ than rice straw mulching. Therefore, the sustained yield of onion crop is achieved by mulching.

\subsection{Essential of CA on water productivity}

A lot of studies argued that conservation agriculture showed CA is one of the water management practice for increasing water productivity as well as increasing irrigable area (Biswas et al., 2017; Assefa, 2018; Belay et al., 2020; Assefa et al., 2021; Yimam et al., 2020). The study of Mukherjee et al. (2012), indicated that CA increased water productivity of tomato crop by $54-93 \%$.

According to Igbadun et al. (2012) mulching with rice straw and black polyethylene significantly improve 
the crop water productivity of onion crop compared with white transparent polyethylene mulch and non-mulch. According to the studies of Rop et al. (2016), irrigation water use efficiency values increased with decreasing water application level. The highest $16.2 \mathrm{~kg} / \mathrm{m}^{3}$ and the lowest $13.1 \mathrm{~kg} / \mathrm{m}^{3}$ IWUE of onion crop was observed at $50 \%$ DI and full irrigation respectively.

According to Assefa et al. (2019) report irrigation water use was substantially lower under CA, $18 \%$ to $45.6 \%$, with a substantial increase in crop yields, $9 \%$ to about two-fold, when compared with CT practice for two folds vegetables. Recently in Ethiopia according to Assefa et al. (2021) CA water productivity of garlic, cabbage, potato, and maize showed increased, by $256 \%, 43 \%, 53 \%$, and $9 \%$ as compared with $\mathrm{CT}$.

\section{Factors Affecting Adoption of Conservation Agriculture (CA) in Ethiopia}

In Ethiopia adoption of Conservation Agriculture is affected by different factors. These constraints are competitive use of mulch; the mulch covers used were crop residues, dried grass, and other local organic materials which farmers also use it to feed their livestock (Assefa et al., 2019), limited potential to grow cover crops during dry season (Umar and Nyanga, 2011), some part of the country farmers burned plant residue by fire.

\section{Opportunities for Adoption of Conservation Agriculture}

In agriculture dependent country like Ethiopia, soil and water conservation is crucial in improving the livelihoods of the rural farm households. This sends an encouraging signal for program designers, implementers, and funding agents. According to (Assefa et al., 2019) CA reducing labour; particularly for tillage, irrigation, and weeding, Increasing water productivity; potential to increase the cycles of vegetable production through increased water productivity. In addition to this CA realize the intended outcomes, future development strategies should consider on how to link such interventions with natural resource management based income generating activities that can provide farmers with short term benefits (Derpsch et al., 2010).

\section{Conclusions}

I have been organized a lot of experimental studies those literature concluded that conservation agriculture is potentially important to improve sustainable Ethiopian agricultural production and productivity. For dry season vegetable production CA can minimize irrigation water by $18 \%$ to $45.6 \%$, and also increase in crop yields by $9 \%$ as compared to CT practice for two folds. For rain fed season also similar effects CA improves crop production and productivity. In addition to this $\mathrm{CA}$ improves soil quality like increasing soil organic matter and carbon protect soil layer for erosions either wind or runoff, to optimize infiltration rate minimize runoff, to crate the path of soil it contributes micro nutrients move easily to plants. Therefore this agricultural practice (CA) should be able to adopt for irrigated and rain fed farms of Ethiopia.

\section{Reference}

Abebe, A., Bedadi, B. \& Bekele, A. Journal of Earth and Environmental Sciences Research.

Abera, D., Beshir, B. \& Liben, F. M. (2020). The Role of Conservation Agriculture for Soil Quality Improvement: A Review. Ethiopian Journal of Agricultural Sciences 30(4): 197-222.

Agerie, N. W. (2013).Determinants of smallholder rural farm households' participation in small scale irrigation and its effect on income in North Gondar zone: a cross-sectional approach (evidence from Dembia Woreda). Mekelle University.

Ahmed, Z. I., Ansar, M., Iqbal, M. \& Minhas, N. M. (2007). Effect of planting geometry and mulching on moisture conservation, weed control and wheat growth under rainfed conditions. Pakistan Journal of Botany 39(4): 1189

Alemu, T. \& Mengistu, A. (2019). Impacts of climate change on food security in Ethiopia: adaptation and mitigation options: a review. Climate change-resilient agriculture and agroforestry: 397-412.

Ariti, A. T., van Vliet, J. \& Verburg, P. H. (2015). Land-use and land-cover changes in the Central Rift Valley of Ethiopia: Assessment of perception and adaptation of stakeholders. Applied Geography 65: 28-37.

Assefa, T., Jha, M., Reyes, M., Tilahun, S. \& Worqlul, A. W. (2019). Experimental evaluation of conservation agriculture with drip irrigation for water productivity in sub-Saharan Africa. Water 11(3): 530.

Assefa, T., Jha, M., Reyes, M., Worqlul, A. W., Doro, L. \& Tilahun, S. (2020). Conservation agriculture with drip irrigation: Effects on soil quality and crop yield in sub-Saharan Africa. Journal of Soil and Water Conservation 75(2): 209-217.

Assefa, T. T. (2018).Experimental and Modeling Evaluation of Conservation Agriculture with Drip Irrigation for Small-Scale Agriculture in Sub-Saharan Africa. North Carolina Agricultural and Technical State University.

Assefa, T. T., Adametie, T. F., Yimam, A. Y., Belay, S. A., Degu, Y. M., Hailemeskel, S. T., Tilahun, S. A., Reyes, M. R. \& Prasad, P. (2021). Evaluating Irrigation and Farming Systems with Solar MajiPump in Ethiopia. Agronomy 11(1): 17. 
Awulachew, S. B. \& Merrey, D. J. (2007). Assessment of small scale irrigation and water harvesting in Ethiopian agricultural development. International Water Management Institute (IWMI), Addis Ababa, Ethiopia.

Bainbridge, D., Tiszler, J., MacAller, R. \& Allen, M. F. (2001). Irrigation and mulch effects on desert shrub transplant establishment. Native Plants Journal 2(1): 25-29.

Bandyopadhyay, K., Hati, K. \& Singh, R. (2009). Management options for improving soil physical environment for sustainable agricultural production: a brief review. Journal of Agricultural Physics 9: 1-8.

Baylis, K., Heckelei, T. \& Hertel, T. W. (2021). Agricultural Trade and Environmental Sustainability. Annual Review of Resource Economics 13.

Belay, S. A., Assefa, T. T., Prasad, P., Schmitter, P., Worqlul, A. W., Steenhuis, T. S., Reyes, M. R. \& Tilahun, S. A. (2020). The response of water and nutrient dynamics and of crop yield to conservation agriculture in the Ethiopian highlands. Sustainability 12(15): 5989.

Beshah, T. (2003). Understanding farmers: explaining soil and water conservation in Konso, Wolaita and Wello, Ethiopia.

Biswas, S., Roy, D., Sarkar, K., Milla, A., Murad, K. \& Anower, M. (2017). Effects of Deficit Irrigation and Mulching on Seed Yield and Water Use of Onion (Allium cepa L.).

Branca, G., Lipper, L., McCarthy, N. \& Jolejole, M. C. (2013). Food security, climate change, and sustainable land management. A review. Agronomy for sustainable development 33(4): 635-650.

CSA, C. S. A. o. E. (2019). Agricultural sample survey 2018/19 report on area and production of major crops for private peasant holdings, Meher season, volume I. Addis Ababa.

Das, T., Bhattacharyya, R., Sudhishri, S., Sharma, A., Saharawat, Y., Bandyopadhyay, K., Sepat, S., Bana, R., Aggarwal, P. \& Sharma, R. (2014). Conservation agriculture in an irrigated cotton-wheat system of the western Indo-Gangetic Plains: Crop and water productivity and economic profitability. Field Crops Research 158: 24-33.

Derpsch, R., Friedrich, T., Kassam, A. \& Li, H. (2010). Current status of adoption of no-till farming in the world and some of its main benefits. International journal of agricultural and biological engineering 3(1): 1-25.

Descheemaeker, K., Bunting, S. W., Bindraban, P., Muthuri, C., Molden, D., Beveridge, M., van Brakel, M., Herrero, M., Clement, F. \& Boelee, E. (2013). Increasing water productivity in agriculture. Managing water and agroecosystems for food security. Wallingford (UK): CABI Publishing: 104-123.

Ethiopia, C. (2011).Agricultural Sample Survey 2010/2011 (2003 EC)(September-December 2010). Volume 1, Report on Area and Production of Major Crops (Private Peasant Holdings, Meher Season). Addis Ababa: CSA.

Fentahun Adametie, T. (2020).Effects of Conservation Agriculture and Irrigation Systems on Crop and Water productivity in The Ethiopian Highlands. Bahir Dar University.

Georgis, K. \& Sinebo, W. (1993).Tillage, soil and water conservation research on maize in Ethiopia. In 1. National Maize Workshop of Ethiopia, Addis Abeba (Ethiopia), 5-7 May 1992: IAR.

Getnet, B., Kebede, L. \& Kim, H. K. (2015). Evaluation of conservation tillage techniques for maize production in the central rift valley of Ethiopia. Ethiopian Journal of Agricultural Sciences 25(2): 47-58.

Ghosh, P., Dayal, D., Bandyopadhyay, K. \& Mohanty, M. (2006). Evaluation of straw and polythene mulch for enhancing productivity of irrigated summer groundnut. Field Crops Research 99(2-3): 76-86.

Girma, M. M. A. \& Seleshi, B. (2007). Irrigation practices in Ethiopia: Characteristics of selected irrigation schemes. IWMI.

Goe, M. (1987). Animal Traction on Smallholder Farms in the Ethiopian Highlands [PhD thesis]. Ithaca, NY: Department of Animal Science, Cornell University.

Govers, G., Merckx, R., van Wesemael, B. \& Van Oost, K. (2017). Soil conservation in the 21st century: why we need smart agricultural intensification. Soil 3(1): 45-59.

Hillel, D. (1991). Research in soil physics: A re-view. Soil Science 151(1): 30-34.

Hobbs, P. R. (2007). Conservation agriculture: what is it and why is it important for future sustainable food production? JOURNAL OF AGRICULTURAL SCIENCE-CAMBRIDGE- 145(2): 127.

Hobbs, P. R., Sayre, K. \& Gupta, R. (2008). The role of conservation agriculture in sustainable agriculture. Philosophical Transactions of the Royal Society B: Biological Sciences 363(1491): 543-555.

Igbadun, H. E., Ramalan, A. \& Oiganji, E. (2012). Effects of regulated deficit irrigation and mulch on yield, water use and crop water productivity of onion in Samaru, Nigeria. Agricultural Water Management 109: 162-169.

Inusah, B. I., Wiredu, A. N., Yirzagla, J., Mawunya, M. \& Haruna, M. (2013). Effects of different mulches on the yield and productivity of drip irrigated onions under tropical conditions. Int. J. Adv. Agric. Res 1: 133140.

IWMI, A. (2009). Wastewater Irrigation and Public Health: From Research to Impact-A roadmap for Ghana. Prepared for Google. org. 
Jat, R., Jat, H. S., Nanwal, R., Yadav, A., Bana, A., Choudhary, K., Kakraliya, S., Sutaliya, J. M., Sapkota, T. B. \& Jat, M. L. (2018). Conservation agriculture and precision nutrient management practices in maize-wheat system: Effects on crop and water productivity and economic profitability. Field Crops Research 222: 111120.

Ji, S. \& Unger, P. W. (2001). Soil water accumulation under different precipitation, potential evaporation, and straw mulch conditions. Soil Science Society of America Journal 65(2): 442-448.

Kader, M., Senge, M., Mojid, M. \& Ito, K. (2017). Recent advances in mulching materials and methods for modifying soil environment. Soil and Tillage Research 168: 155-166.

Kar, G. \& Kumar, A. (2007). Effects of irrigation and straw mulch on water use and tuber yield of potato in eastern India. Agricultural Water Management 94(1-3): 109-116.

Kar, G. \& Singh, R. (2004). Soil water retention - transmission studies and enhancing water use efficiency of winter crops through soil surface modification. Indian Journal of Soil Conservation 8: 18-23.

Kumar, S. D. \& Lal, B. R. (2012). Effect of mulching on crop production under rainfed condition: A Review. Int. J. Res. Chem. Environ 2(2): 8-20.

Lal Bhardwaj, R. (2013). Effect of mulching on crop production under rainfed condition-a review. Agricultural Reviews 34(3).

Lal, R. (1976). No - tillage effects on soil properties under different crops in Western Nigeria. Soil science society of America journal 40(5): 762-768.

Leye, M. T. (2007). Conservation Tillage Systems and Water Productivity-Implications for Smallholder Farmers in Semi-Arid Ethiopia: PhD, UNESCO-IHE Institute for Water Education, Delft, The Netherlands. CRC Press.

Liben, F., Tadesse, B., Tola, Y., Wortmann, C., Kim, H. \& Mupangwa, W. (2018). Conservation agriculture effects on crop productivity and soil properties in Ethiopia. Agronomy Journal 110(2): 758-767.

Liu, Y., Gao, M., Wu, W., Tanveer, S. K., Wen, X. \& Liao, Y. (2013). The effects of conservation tillage practices on the soil water-holding capacity of a non-irrigated apple orchard in the Loess Plateau, China. Soil and Tillage Research 130: 7-12.

Liu, Y., Li, S., Chen, F., Yang, S. \& Chen, X. (2010). Soil water dynamics and water use efficiency in spring maize (Zea mays L.) fields subjected to different water management practices on the Loess Plateau, China. Agricultural Water Management 97(5): 769-775.

Malik, A., Shakir, A. S., Ajmal, M., Khan, M. J. \& Khan, T. A. (2017). Assessment of AquaCrop model in simulating sugar beet canopy cover, biomass and root yield under different irrigation and field management practices in semi-arid regions of Pakistan. Water Resources Management 31(13): 4275-4292.

Marenya, P., Kassie, M., Jaleta, M., Rahut, D. B. \& Erenstein, O. (2015).Adoption of conservation agriculture under alternative agricultural policy and market access indicators: Evidence from Eastern and Southern Africa.

Mebratu, A., Alemayehu, S., Taffesse, P., Dorosh, D. \& Sinafikeh, A. (2015). Crop production in Ethiopia: Regional patterns and trends. The International food policy research institute sustainable solutions for ending hunger and poverty. Summary of ESSP II Working Paper 16: 1-5.

Meemken, E.-M. \& Qaim, M. (2018). Organic agriculture, food security, and the environment. Annual Review of Resource Economics 10: 39-63.

Melesse, A. M., Weng, Q., Thenkabail, P. S. \& Senay, G. B. (2007). Remote sensing sensors and applications in environmental resources mapping and modelling. Sensors 7(12): 3209-3241.

Mendes, D. M. \& Paglietti, L. (2015). Ethiopia: Irrigation market brief. FAO, Rome, Italy.

Mubarak, I. \& Hamdan, A. (2018). Onion crop response to regulated deficit irrigation under mulching in dry Mediterranean region. Journal of Horticultural Research 26(1): 87-94.

Muhanji, G., Roothaert, R. L., Webo, C. \& Stanley, M. (2011). African indigenous vegetable enterprises and market access for small-scale farmers in East Africa. International Journal of Agricultural Sustainability 9(1): 194-202.

Mukherjee, A., Sarkar, S. \& Chakraborty, P. (2012). Marginal analysis of water productivity function of tomato crop grown under different irrigation regimes and mulch managements. Agricultural Water Management 104: 121-127.

Munshower, F. (1994).Plant growth on ash disposal ponds. Great Plains-Rocky Mountain Hazardous Substance Research Center, Manhattan ....

Nangia, V., Jiantao, D., Changrong, Y., Xurong, M., Wenqing, H., Shuang, L. \& Qin, L. (2010). Effects of conservation agriculture on land and water productivity in Yellow River Basin, China. International journal of agricultural and biological engineering 3(2): 5-17.

Neelakantam, T. \& Naidu, P. D. (2016). Agricultural Contribution in Development of Ethiopia Issues and Challenges. ITIHAS The Journal of Indian Management 6(1): 38-54.

Nkansah, G., Owusu, E., Bonsu, K. \& Dennis, E. (2003). Effect of Mulch Types on Growth, Yield and Fruit 
Quality of Tomato (Lycopersicon esculentum Mill.). Ghana Journal of Horticulture 2: 55-64.

Nyssen, J., Govaerts, B., Araya, T., Cornelis, W. M., Bauer, H., Haile, M., Sayre, K. \& Deckers, J. (2011). The use of the marasha ard plough for conservation agriculture in Northern Ethiopia. Agronomy for sustainable development 31(2): 287-297.

OLJAČA, J., BROĆIĆ, Z., MOMIROVIĆ, N., POŠTIĆ, D., PANTELIĆ, D., RUDIĆ, J. \& MOMČILOVIĆ, I. (2018). EFFECTS OF CULTIVAR AND MULCHING ON THE POTATO YIELD. AGROFOR 3(1).

Ramankutty, N., Mehrabi, Z., Waha, K., Jarvis, L., Kremen, C., Herrero, M. \& Rieseberg, L. H. (2018). Trends in global agricultural land use: implications for environmental health and food security. Annual review of plant biology 69: 789-815.

Ranjan, P., Patle, G., Prem, M. \& Solanke, K. (2017). Organic Mulching-A Water Saving Technique to Increase the Production of Fruits and Vegetables. Current Agriculture Research Journal 5(3): 371-380.

Rockström, J., Kaumbutho, P., Mwalley, J., Nzabi, A., Temesgen, M., Mawenya, L., Barron, J., Mutua, J. \& Damgaard-Larsen, S. (2009). Conservation farming strategies in East and Southern Africa: Yields and rain water productivity from on-farm action research. Soil and tillage research 103(1): 23-32.

Rop, D. K., Kipkorir, E. C. \& Taragon, J. K. (2016). Effects of deficit irrigation on yield and quality of onion crop. J. Agric. Sci 8(3): 112-126.

Saeed, R. \& Ahmad, R. (2009). Vegetative growth and yield of tomato as affected by the application of organic mulch and gypsum under saline rhizosphere. Pak. J. Bot 41(6): 3093-3105.

Seifu, W., Yemane, T., Bedada, S., Alemu, T. \& Boshoftu, E. (2017). Evaluation of Different Mulching Practices on Garlic (Allium sativum L.) Growth Parameters under Irrigated Condition in Fiche, North Shoa Ethiopia. Evaluation 7(9).

Shirgure, P., Sonkar, R., Singh, S. \& Panigrahi, P. (2003). Effect of different mulches on soil-moisture conservation, weed reduction, growth and yield of drip-irrigated Nagpur mandarin (Citrus reticulata). Indian Journal of Agricultural Science 73(3): 148-152.

Stagnari, F., Ramazzotti, S. \& Pisante, M. (2009). Conservation agriculture: a different approach for crop production through sustainable soil and water management: a review. organic farming, pest control and remediation of soil pollutants: 55-83.

Stirling, G. \& Eden, L. (2008). The impact of organic amendments, mulching and tillage on plant nutrition, Pythium root rot, root-knot nematode and other pests and diseases of capsicum in a subtropical environment, and implications for the development of more sustainable vegetable farming systems. Australasian Plant Pathology 37(2): 123-131.

Tao, Z., Li, C., Li, J., Ding, Z., Xu, J., Sun, X., Zhou, P. \& Zhao, M. (2015). Tillage and straw mulching impacts on grain yield and water use efficiency of spring maize in Northern Huang-Huai-Hai Valley. The Crop Journal 3(5): 445-450.

Teame, G., Tsegay, A. \& Abrha, B. (2017). Effect of organic mulching on soil moisture, yield, and yield contributing components of sesame (Sesamum indicum L.). International Journal of Agronomy 2017.

Umar, B. \& Nyanga, P. (2011).Conservation agriculture and rainfall variability in Zambia: is CA a promising option for responding to droughts and floods. In 5th World Congress on Conservation Agriculture, 26-29.

Uwah, D. \& Iwo, G. (2011). Effectiveness of organic mulch on the productivity of maize (Zea mays L.) and weed growth. J. Anim. Plant Sci 21(3): 525-530.

van der Molen, P. (2017). Food security, land use and land surveyors. Survey review 49(353): 147-152.

Yi, L., Shenjiao, Y., Shiqing, L., Xinping, C. \& Fang, C. (2010). Growth and development of maize (Zea mays L.) in response to different field water management practices: Resource capture and use efficiency. Agricultural and Forest Meteorology 150(4): 606-613.

Yimam, A. Y., Assefa, T. T., Adane, N. F., Tilahun, S. A., Jha, M. K. \& Reyes, M. R. (2020). Experimental evaluation for the impacts of conservation agriculture with drip irrigation on crop coefficient and soil properties in the sub-humid Ethiopian Highlands. Water 12(4): 947.

Zibilske, L. \& Makus, D. (2009). Black oat cover crop management effects on soil temperature and biological properties on a Mollisol in Texas, USA. Geoderma 149(3-4): 379-385. 